\title{
Selective recognition of acetylcholine over choline by a fluorescent cage
}

Long, A., Fantozzi, N., Pinet, S., Genin, E., Petuya, R., Begue, D., Robert, V., Dutasta, J. P., Gosse, I., Martinez, A.

\begin{abstract}
A fluorescent hemicryptophane has been synthesized and can be used as a turn on receptor of acetylcholine. A binding constant of $2.4 \times 10^{4} \mathrm{M}^{-1}$ was measured for this neurotransmitter, and its selective and sensitive detection over choline and choline phosphate was achieved. NMR and DFT calculations provide insight into the interactions involved in this selective recognition process.
\end{abstract}

Recognition of small molecules, like neuro-transmitters or carbohydrates, plays a crucial role in numerous biological processes. $^{1-11}$ For instance, during the transmission of the neuronal information, acetylcholine ( $\mathrm{ACh}$ ) is delivered in the synaptic cleft and then bonds to its receptor to permit the signal to pass from the presynaptic (axone) to the postsynaptic (dendrite) site. Then, ACh is hydrolysed to acetic acid and choline (Ch) by an enzyme, acetylcholinesterase, in order to prevent overstimulation that could result from its accumulation in the synaptic cleft. ${ }^{12-15}$ Thus, the selective detection of ACh by synthetic receptors arouses a considerable interest as it could allow for better understanding of the molecular machinery responsible for the transmission and regulation of the nervous impulse. ${ }^{16-20}$ Due to the high sensitivity, fast response time, high spatial resolution and non-destructive procedures of fluorescence-based optical methods, ${ }^{21,22}$ fluorescent hosts capable of Ach complexation have been described. ${ }^{23-27}$ However, the $\mathrm{ACh} / \mathrm{Ch}$ selectivity observed with the natural synaptic receptor is difficult to achieve with synthetic ones, ${ }^{28-32}$ and the design of a fluorescent receptor capable of selective complexation of $\mathrm{ACh}$ remains a challenge. ${ }^{33-36}$ Indeed, most of the time, either no selectivity, or a selectivity in favour of Ch over Ach is observed. ${ }^{28-32}$ Only few examples of non-fluorescent molecular receptors showing a selectivity in favour of $\mathrm{ACh}$ over $\mathrm{Ch}$ were previously reported. ${ }^{34,35}$ Fluorescent probes displaying this expected selectivity are even more scarce and the selectivity remains modest (typically between 1.4 and 2.2). ${ }^{27,33}$

Hemicryptophanes are host compounds built from a cyclotriveratrylene (CTV) unit, linked to another $C_{3}$-symmetrical moiety, ${ }^{37}$ and can, depending on their cavity size and shape, complex selectively different guests including ammonium and zwitterionic neurotransmitters. $^{38-42}$ For instance, hemicryptophane 1 can efficiently complex taurine $\left(K=5.0 \times 10^{5} \mathrm{M}^{-1}\right)$ but not choline and choline phosphate, ${ }^{43}$ whereas hemicryptophane 2 is able to recognize selectively choline phosphate $(K=$ $\left.4.2 \times 10^{5} \mathrm{M}^{-1}\right)$ over choline $\left(K=7.0 \times 10^{3} \mathrm{M}^{-1}\right)$; meanwhile, no complexation is observed for taurine. ${ }^{44}$ In this work, we report on the synthesis of the new hemicryptophane 3 bearing naphthalene units in the linkers (Scheme 1). It was anticipated that the CTV unit should interact with the ammonium part of the neurotransmitter and that the naphthalene linkers should confer fluorescent properties to the host. This fluorescent cage

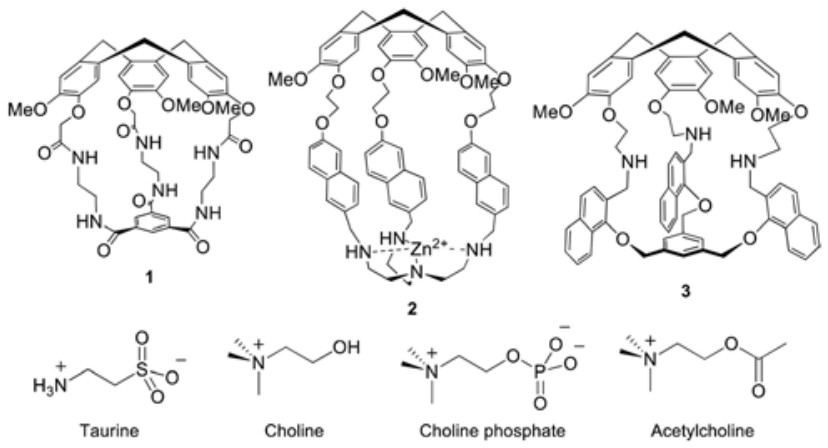

Scheme 1 Structure of hemicryptophanes 1-3 and neurotransmitters. 
3 was able to recognize ACh with a turn on signal and with a selectivity over $\mathrm{Ch}$ and choline phosphate. Finally, the interactions involved in the complexation between the host and the guest were investigated by the means of NMR analysis and DFT calculations.

The synthetic pathway leading to fluorescent hemicryptophane 3 is shown in Scheme 2. CTV- $\mathrm{NH}_{2} \mathbf{5}$ is obtained according to the previously published procedure: vanillyl alcohol reacts first with dibromoethane in $\mathrm{EtOH}$ and the subsequent cyclization in $\mathrm{MeCN}$ using $\mathrm{Sc}(\mathrm{OTf})_{3}$ as catalyst gives CTV-Br $4 .^{45}$ Substitution of the three bromines by azide groups, followed by Staudinger's reaction affords CTV-NH ${ }_{2} 5$ with $15 \%$ overall yield. ${ }^{46}$ The nucleophilic substitution between 1,3,5-tribromomethyl-benzene and 1-hydroxy-2naphthaldehyde in $\mathrm{EtOH}$ in the presence of $\mathrm{NaOH}$ gives the $C_{3}$-trialdehyde moiety 6 in $51 \%$ yield. Final reductive amination between CTV- $\mathrm{NH}_{2} 5$ and 6 in a 1/1 mixture of $\mathrm{CHCl}_{3}$ and $\mathrm{MeOH}$ provides hemicryptophane 3 in $35 \%$ yield.

The $C_{3}$ symmetry of 3 in solution is corroborated by the ${ }^{1} \mathrm{H}$ NMR spectrum (Fig. 1). The expected signals of the CTV

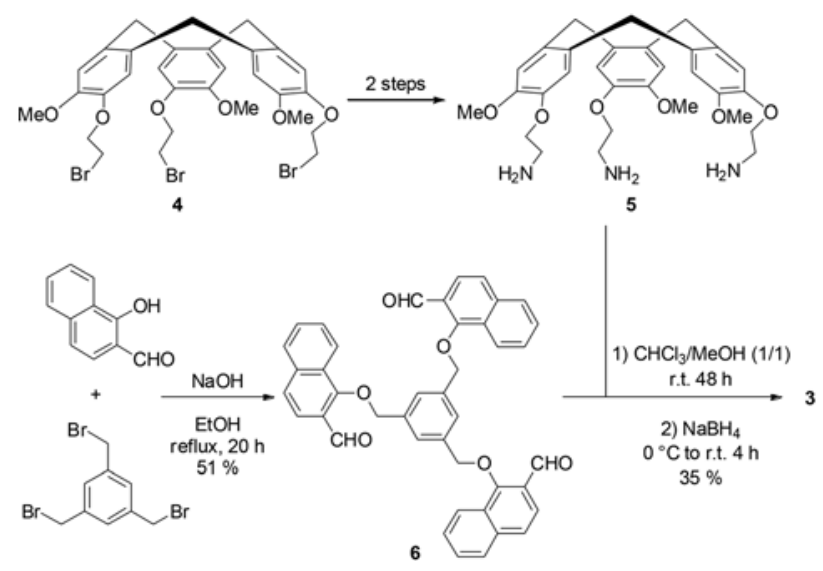

Scheme 2 Synthesis of the fluorescent hemicryptophane host 3.

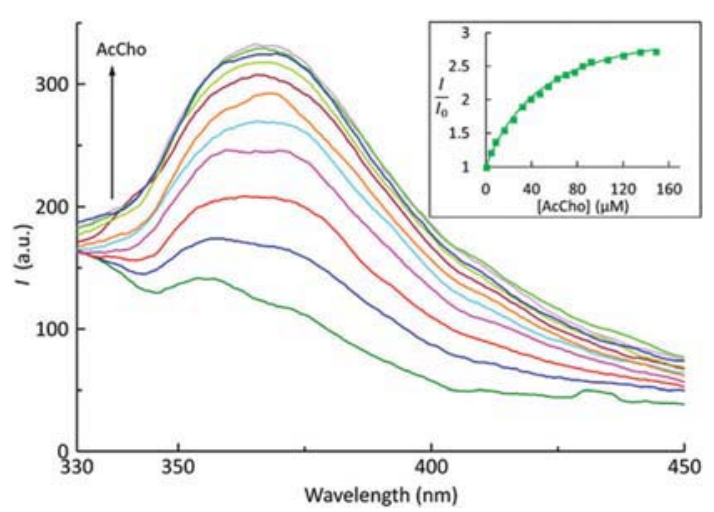

Fig. 1 Fluorescence titration of a $5 \mu \mathrm{M}$ solution of 3 in DMSO $+2 \%$ $\mathrm{H} 2 \mathrm{O}$ excited at $290 \mathrm{~nm}$ with $\mathrm{ACh}$ at $298 \mathrm{~K}$ (counterion $\mathrm{Cl}^{-}$). Inset: Evolution of the relative fluorescence intensity at $362 \mathrm{~nm}$ as a function of the concentration of added Ach. part can be observed: the two specific doublets of the $\mathrm{ArCH}_{2}$ methylene bridge (I) at 4.75 and $3.53 \mathrm{ppm}$, the two singlets at 6.93 and $6.79 \mathrm{ppm}$ for the aromatic protons (F, G) and a singlet at $3.67 \mathrm{ppm}$ for the methoxy groups $(\mathbf{L})$. The aromatic protons of the naphthalene linkers appear between 7.4 and $8.1 \mathrm{ppm}$ and overlap with the aromatic proton of the lower part around $7.45 \mathrm{ppm}$, whereas the diastereotopic aliphatic protons $\mathbf{H}$ exhibit two doublets at 4.87 and $4.79 \mathrm{ppm}$, respectively.

Then, we examined the complexation of acetylcholine in the cavity of 3 by evaluating the changes in the fluorescence emission of a $5 \mu \mathrm{M}$ solution of 3 in DMSO $+2 \% \mathrm{H}_{2} \mathrm{O}$ upon addition of a solution of the guest in the same solvents. A remarkable increase of fluorescence intensity $I$ is observed at $362 \mathrm{~nm}$, up to a factor 3 (Fig. 2). A FRET process between two fluorescent naphthalene units can account for this experimental result: ${ }^{22,47}$ the distance between the fluorophore and the quencher becomes longer when the guest is complexed in the cavity, decreasing the quenching of fluorescence. A binding constant of $2.4 \times 10^{4} \mathrm{~L} \mathrm{~mol}^{-1}$ was determined according to a $1: 1$ association model by fitting the relative fluorescence intensity as a function of the concentration of ACh (Fig. 2). Thus, 3 turns out to be efficient for detection by the fluorescence of ACh even at micromolar concentrations, in a competitive media, with a turn on signal in the presence of this neurotransmitter.

Furthermore, we studied the selectivity for fluorescent detection between ACh, $\mathrm{Ch}$ and choline phosphate. Titration of $\mathrm{Ch}$ and choline phosphate in DMSO with $2 \% \mathrm{H}_{2} \mathrm{O}$ was carried out (Fig. S10-S12, ESI $\dagger$ ). Lower binding constants $\left(5.9 \times 10^{3} \mathrm{~L} \mathrm{~mol}^{-1}\right.$ and $4.2 \times 10^{3} \mathrm{~L} \mathrm{~mol}^{-1}$ for $\mathrm{Ch}$ and choline phosphate, respectively) compared with acetylcholine were obtained. Moreover, as shown in Fig. 3, the sensitivity is much higher for the detection of ACh: a double increase of the intensity of the fluorescence signal is observed for a concentration of $138 \mu \mathrm{M}$ for $\mathrm{Ch}$ (4 times higher than the one for ACh) or $227 \mu \mathrm{M}$ for choline phosphate ( 6.5 times higher than the one for ACh). These results are consistent with the binding constants and underline the fact that cage 3 is an efficient receptor for both selective and sensitive detection of acetylcholine over choline and choline phosphate by fluorescence spectroscopy.

More insights into the inclusion complex of acetylcholine within the cavity of the hemicryptophane 3 were obtained by

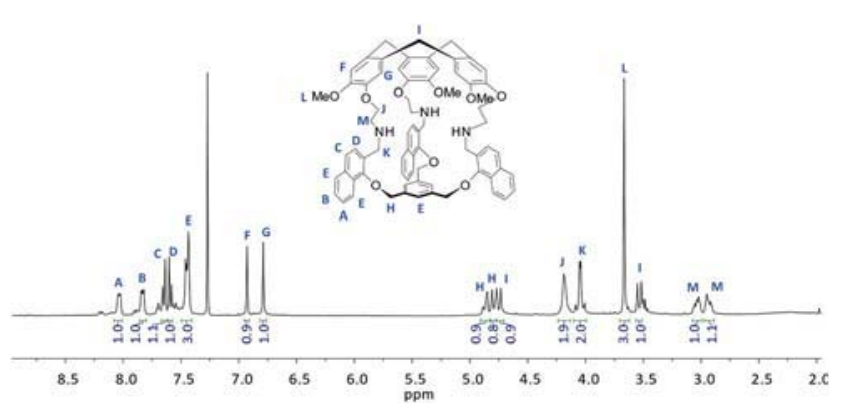

Fig. $2{ }^{1} \mathrm{H}$ NMR spectrum (400 $\mathrm{MHz}_{3} \mathrm{CDCl}_{3}, 298 \mathrm{~K}$ ) of 3. 


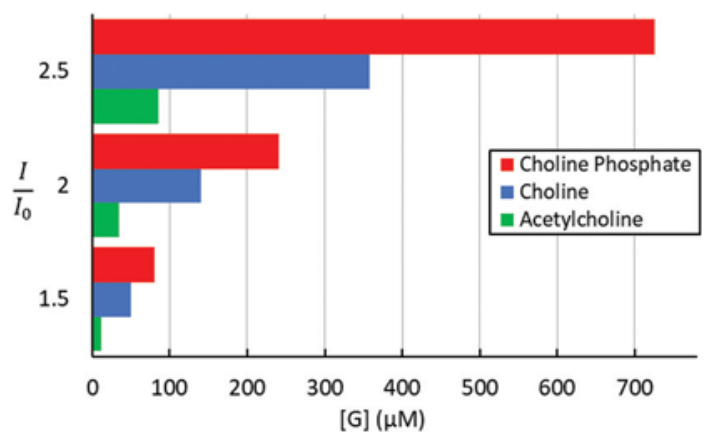

Fig. 3 Increase by $50 \%, 100 \%$ and $150 \%$ of the normalized intensity of a $5 \mu \mathrm{M}$ solution of 3 in DMSO $+2 \% \mathrm{H}_{2} \mathrm{O}$ with respect to the concentration of the corresponding added guest at $298 \mathrm{~K}$ (counterion $\mathrm{Cl}^{-}$for $\mathrm{ACh}, \mathrm{Ch}$ and $\mathrm{Cl}^{-}$and $\mathrm{Ca}^{2+}$ for choline phosphate).

${ }^{1} \mathrm{H}$ NMR experiments. The addition of a $5 \mathrm{mM}$ solution of acetylcholine picrate in a $95 / 5$ mixture of $\mathrm{CDCl}_{3} / \mathrm{MeOD}$ to a $1 \mathrm{mM}$ solution of 3 in the same mixture of solvents induces changes in chemical shifts of the proton signals of the cage and the guest (Fig. S14, ESI $\dagger$ ) showing that host-guest exchange is fast on the NMR timescale. During this titration experiment, both the $\mathrm{CH}_{2}$ and $\left(\mathrm{CH}_{3}\right)_{3} \mathrm{~N}$ protons of acetylcholine are shifted downfield. These results suggest that these protons are in the shielding region of the aromatic rings of the hemicryptophane $\mathbf{3}$, and that ACh is probably trapped inside the cavity of 3. The sharp and well-defined signals at 7.61 and $7.55 \mathrm{ppm}$ corresponding to the two aromatic protons of the naphthalene of host $\mathbf{3}$ were used to obtain the titration curves (Fig. S13, ESI $\dagger$ ). The complexation-induced shifts were plotted as a function of the guest/host ratio and were fitted using the Bindfit program..$^{48} \mathrm{An}$ association constant for acetylcholine of $5.5 \times 10^{3} \mathrm{~L} \mathrm{~mol}^{-1}$ was measured, with a 1:1 host: guest stoichiometry. This binding constant differs a little from that obtained by fluorescence titration, probably because the solvent is not the same in the two sets of experiments.

Then, we decided to examine more precisely the structure of the inclusion complex between the guest and the host. DFT calculations were performed, providing the minimized structure shown in Fig. 4. It can be observed that the ACh guest is partially encapsulated in the cavity of hemicryptophane 3 , with the ammonium moiety capped by the CTV unit and the ester function going through one window of the cage. This is consistent with the X-ray structure previously reported by Makita et al. for another ACh@hemicryptophane complex. ${ }^{49}$ A deeper inspection of the optimized geometry shown in Fig. 4 reveals that cation $-\pi$ and $\mathrm{CH}-\pi$ interactions occurs between the CTV unit and the ammonium group. Several distances between the $-\mathrm{N}\left(\mathrm{CH}_{3}\right)_{3}$ groups of ACh and the aromatic rings of the CTV or the aromatic unit in the south part lie in the 2.4 to $2.6 \AA$ range. Hydrogen bonding between the oxygen atoms located on the CTV moiety and the $\mathrm{CH}_{2}$ and $\mathrm{C}(\mathrm{O})-\mathrm{CH}_{3}$ protons of ACh are observed with $\mathrm{O} \cdots \mathrm{H}$ distances between 2.48 and $2.53 \AA$. Similarly, the $\mathrm{H}$-bond between the $\mathrm{Ar}-\mathrm{CH}_{2}$ protons of the host and $\mathrm{C}=\mathrm{O}$ oxygen of $\mathrm{ACh}$ is found $(2.5 \AA)$. These two latter

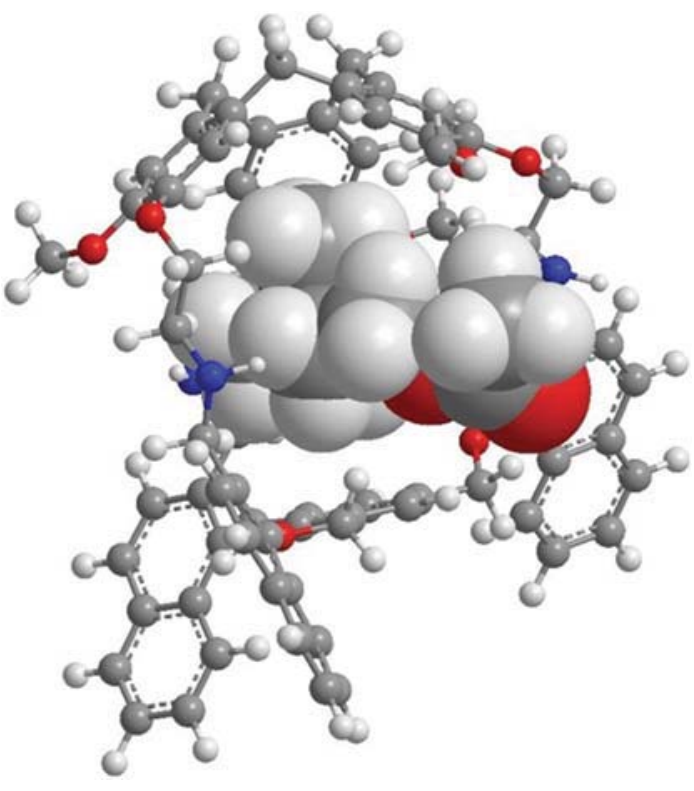

Fig. 4 DFT-optimized structure of the encapsulated acetylcholine guest within the cavity of the fluorescent hemicryptophane 3 .

interactions cannot occur with $\mathrm{Ch}$, because of the lack of ester group, and could account for the ACh/Ch selectivity observed.

In conclusion, we have described the synthesis of a new hemicryptophane cage with fluorescent naphthalene groups on its linkers. This cage can be used as a sensitive turn on receptor of acetylcholine. Beside the high binding constant observed for this guest, in competitive media, this host displays also selectivity and good sensitivity towards acetylcholine over choline and choline phosphate. DFT calculations and NMR titration experiments were then performed to examine the structure of the complex. Studies for longer wavelength fluorescence detection and detection in water using hemicryptophanes are in progress.

1 J. K. M. Sanders, Chem. - Eur. J., 1998, 4, 1378-1383.

2 C.-H. Wong, Carbohydrate-Based Drug Discovery, Wiley-VCH, Weinheim, 2003.

3 (a) M. Mazik, Chem. Soc. Rev., 2009, 38, 935-956; (b) A. P. Davis, Org. Biomol. Chem., 2009, 7, 3629-3638; (c) F. Amrhein, J. Lippe and M. Mazik, Org. Biomol. Chem., 2016, 14, 10648-10659; (d) P. Ríos, T. J. Mooibroek, T. S. Carter, C. Williams, M. R. Wilson, M. P. Crump and A. P. Davis, Chem. Sci., 2017, 8, 4056-4061; (e) P. K. Mandal, B. Kauffmann, H. Destecroix, Y. Ferrand, A. P. Davis and I. Huc, Chem. Commun., 2016, 52, 9355- 
9358; (f) N. Chandramouli, Y. Ferrand, G. Lautrette, B. Kauffmann, C. D. Mackereth, M. Laguerre, D. Dubreuil and I. Huc, Nat. Chem., 2015, 7, 334-341; $(g)$ R. A. Tromans, T. S. Carter, L. Chabanne, M. P. Crump, H. Li, J. V. Matlock, M. G. Orchard and A. P. Davis, Nat. Chem., 2019, 11, 52-56; (h) S. Saha, B. Kauffmann, Y. Ferrand and I. Huc, Angew. Chem., Int. Ed., 2018, 57, 13542-11346.

4 C.-H. Wong, Carbohydrate-Based Drug Discovery, Wiley-VCH, Weinheim, 2003.

5 J. Roth, Chem. Rev., 2002, 102, 285-304.

6 T. Angata and A. Varki, Chem. Rev., 2002, 102, 439-470.

7 B. Ernst, G. W. Hart and P. Sinaý, Carbohydrates in Chemistry and Biology, Wiley-VCH, Weinheim, 2000.

8 J. C. Ma and D. A. Dougherty, Chem. Rev., 1997, 97, 1303-1324. 9 H.-J. Schneider, Angew. Chem., Int. Ed., 2009, 48, 3924-3977.

10 E. A. Meyer, R. K. Castellano and F. Diederich, Angew. Chem., Int. Ed., 2003, 42, 4120-4120.

11 L. M. Salonen, M. Ellermann and F. Diederich, Angew. Chem., Int. Ed., 2011, 50, 4808-4842.

12 L. Descarries and D. Umbriaco, Semin. Neurosci., 1995, 7, 309-318.

13 T.-H. Tsai, J. Chromatogr. B: Biomed. Sci. Appl., 2000, 747, 111-122.

14 E. R. Kandel, J. H. Schwartz and T. M. Jessell, Principles of Neural Science, McGraw Hill, United States, 4th edn., 2000.

15 J. R. Cooper, F. E. Bloom and R. H. Roth, The biochemical basis of neuropharmacology, Oxford University Press, New York, 1991.

16 M. Dhaenens, L. Lacombe, J.-M. Lehn and J.-P. Vigneron, J. Chem. Soc., Chem. Commun., 1984, 1097-1099.

17 D. A. Dougherty and D. A. Stauffer, Science, 1990, 250, 1558-1560.

18 J.-M. Lehn, R. Meric, J.-P. Vigneron, M. Cesario, J. Guilhem, C. Pascard, Z. Asfari and J. Vicens, Supramol. Chem., 1995, 5, 97-103.

19 S. Bartoli and S. Roelens, J. Am. Chem. Soc., 2002, 124, 8307-8315.

20 F. H. Zelder and J. R. Rebek Jr., Chem. Commun., 2006, 753754.

21 A. P. de Silva, H. Q. N. Gunaratne, T. Gunnlaugsson, A. J. M. Huxley, C. P. McCoy, J. T. Rademacher and T. E. Rice, Chem. Rev., 1997, 97, 1515-1566.

22 T. Pradhan, H. S. Jung, J. H. Jang, T. W. Kim, C. Kang and J. S. Kim, Chem. Soc. Rev., 2014, 43, 4684-4713.

23 (a) M. Inouye, K. Hashimoto and K. Isagawa, J. Am. Chem. Soc., 1994, 116, 5517-5518; (b) S.-D. Tan, W.-H. Chen, A. Satake, B. Wang, Z.-L. Xu and Y. Kobuke, Org. Biomol. Chem., 2004, 2, 2719-2721.

24 K. N. Koh, K. Araki, A. Ikeda, H. Otsuka and S. Shinkai, J. Am. Chem. Soc., 1996, 118, 755-758.

25 Y. Liu, L. Perez, M. Mettry, A. D. Gill, S. R. Byers, C. J. Easley, C. J. Bardeen, W. Zhong and R. J. Hooley, Chem. Sci., 2017, 8, 3960-3970.

26 N. Korbakov, P. Timmerman, N. Lidich, B. Urbach, A. Sáar and S. Yitzchaik, Langmuir, 2008, 24, 2580-2587.
27 (a) M.-L. Dumartin, C. Givelet, P. Meyrand, B. Bibal and I. Gosse, Org. Biomol. Chem., 2009, 7, 2725-2728; (b) L. Erieau-Peyrard, C. Coiffier, P. Bordat, D. Bégué, S. Chierici, S. Pinet, I. Gosse, I. Baraille and R. Brown, Phys. Chem. Chem. Phys., 2015, 17, 4168-4174.

28 (a) H.-J. Schneider, D. Güttes and U. Schneider, Angew. Chem., Int. Ed. Engl., 1986, 25, 647-649; (b) C. Jia, W. Zuo, D. Yang, Y. Chen, L. Cao, R. Custelcean, J. Hostaš, P. Hobza, R. Glaser, Y.-Y. Wang, X.-J. Yang and B. Wu, Nat. Commun., 2017, 8, 938; (c) R. J. Hooley, H. Van Anda and J. Rebek, J. Am. Chem. Soc., 2007, 129, 13464-13473.

29 (a) P. Ballester, A. Shivanyuk, A. R. Far and J. Rebek, J. Am. Chem. Soc., 2002, 124, 14014-14016; (b) P. Ballester and M. A. Sarmentero, Org. Lett., 2006, 8, 3477-3480; (c) D.-S. Guo, V. D. Uzunova, X. Su, Y. Liu and W. M. Nau, Chem. Sci., 2011, 2, 1722-1734.

30 (a) F. Hof, L. Trembleau, E. C. Ullrich and J. Rebek Jr., Angew. Chem., Int. Ed., 2003, 42, 3150-3153; (b) A. L. Whiting and F. Hof, Org. Biomol. Chem., 2012, 10, 6885-6892; (c) C. S. Beshara and F. Hof, Can. J. Chem., 2010, 88, 1009-1016; (d) A. L. Whiting, N. M. Neufeld and F. Hof, Tetrahedron Lett., 2009, 50, 7035-7037.

31 (a) L. Garel, B. Lozach, J.-P. Dutasta and A. Collet, J. Am. Chem. Soc., 1993, 115, 11652-11653; (b) L. Peyrard, S. Chierici, S. Pinet, P. Batat, G. Jonusauskas, N. Pinaud, P. Meyrand and I. Gosse, Org. Biomol. Chem., 2011, 9, 8489.

32 H. Abdoul-Carime, B. Farizon, M. Farizon, J.-C. Mulatier, J.-P. Dutasta and H. Chermette, Phys. Chem. Chem. Phys., 2015, 17, 4448-4457.

33 H. Bakirci and W. Nau, Adv. Funct. Mater., 2006, 16, 237242.

34 (a) H. Abdoul-Carime, M. M. Harb, C. G. Montano, C. Teyssier, B. Farizon, M. Farizon, J. Vachon, S. Harthong, J.-P. Dutasta, E. Jeanneau and T. D. Märk, Chem. Phys. Lett., 2012, 533, 82-86; (b) T. Jin, Sensors, 2010, 10, 2438-2449.

35 J. Ma, Q. Meng, X. Hu, B. Li, S. Ma, B. Hu, J. Li, X. Jia and C. Li, Org. Lett., 2016, 18, 5740-5743.

36 M. Shen, Z. Qu, J. DesLaurier, T. M. Welle, J. V. Sweedler and R. Chen, J. Am. Chem. Soc., 2018, 140, 7764-7768.

37 (a) D. Zhang, A. Martinez and J.-P. Dutasta, Chem. Rev., 2017, 117, 4900-4942; (b) M. J. Hardie, Chem. Soc. Rev., 2010, 39, 516-527.

38 O. Perraud, V. Robert, A. Martinez and J.-P. Dutasta, Chem. - Eur. J., 2011, 17, 13405-13408.

39 A. Schmitt, B. Chatelet, S. Collin, J.-P. Dutasta and A. Martinez, Chirality, 2013, 25, 475-479.

40 A. Schmitt, O. Perraud, E. Payet, B. Chatelet, B. Bousquet, M. Valls, D. Padula, L. D. Bari, J.-P. Dutasta and A. Martinez, Org. Biomol. Chem., 2014, 12, 4211-4217.

41 J. R. Cochrane, A. Schmitt, U. Wille and C. A. Hutton, Chem. Commun., 2013, 49, 8504-8506.

42 S. Lefevre, D. Zhang, E. Godart, M. Jean, N. Vanthuyne, J.-C. Mulatier, J.-P. Dutasta, L. Guy and A. Martinez, Chem. - Eur. J., 2016, 22, 2068-2074.

43 O. Perraud, V. Robert, H. Gornitzka, A. Martinez and J.-P. Dutasta, Angew. Chem., Int. Ed., 2012, 51, 504-508. 
44 D. Zhang, G. Gao, L. Guy, V. Robert, J.-P. Dutasta and A. Martinez, Chem. Commun., 2015, 51, 2679-2682.

45 B. Chatelet, E. Payet, O. Perraud, P. Dimitrov-Raytchev, L.-L. Chapellet, V. Dufaud, A. Martinez and J.-P. Dutasta, Org. Lett., 2011, 13, 3706-3709.

46 A. Long, O. Perraud, M. Albalat, V. Robert, J.-P. Dutasta and A. Martinez, J. Org. Chem., 2018, 83, 6301-6306.
47 I. Leray and B. Valeur, Eur. J. Inorg. Chem., 2009, 2009, 3525-3535.

48 D. B. Hibbert and P. Thordarson, Chem. Commun., 2016, 52, 12792-12805.

49 Y. Makita, N. Katayama, H.-H. Lee, T. Abe, K. Sogawa, A. Nomoto, S. Fujiwara and A. Ogawa, Tetrahedron Lett., 2016, 57, 5112-5115. 